Revista de

Contabilidade e

Organizações

www.rco.usp.br
DOI: http://dx.doi.org/10.11606/rco.v11i30.137816
Journal of

Accounting and

Organizations

www.rco.usp.br

\title{
The practical relevance of public sector research: The potential contributions of the interventionist approach
}

A relevância prática da pesquisa no setor público: a potencial contribuição da abordagem intervencionista

Enrico Bracci ${ }^{\mathrm{a}}$

${ }^{a}$ University of Ferrara

Keywords

Interventionist approach.

Public sector.

Learning process.
Palvras-chave

Abordagem intervencionista.

Setor público.

Processo de aprendizagem

\section{Article Info}

Received: 09 September 2017

Accepted: 25 September 2017

\begin{abstract}
The practical relevance of accounting research is one of the main issue currently present in the debate. Scholars engagement and impact of accounting research are all the more required nowadays. Interventionist research (IVR) is considered a potential methodology that allows researchers to contribute to the advancement of both practice and theory. The aim of this paper is to present an analysis of the characteristics of IVR, providing guidance on how it can provide a fruitful methodology to bridge academics and practitioners in the context of public sector research.
\end{abstract}

\begin{abstract}
Resumo
A relevância prática da pesquisa em contabilidade é uma das questões mais presentes atualmente no debate na área. $O$ engajamento dos acadêmicos e o impacto da pesquisa em contabilidade são mais que necessários nos dias atuais. A pesquisa intervencionista (IVR, sigla para Interventionist Research) é considerada uma metodologia que em potencial permitiria pesquisadores contribuírem com o avanço tanto das práticas quando da teoria. O objetivo deste artigo é apresentar uma análise das características da IVR, oferecendo um guia em esta metodologia pode ser útil para construir a ponte entre acadêmicos e praticantes no contexto da pesquisa no setor público.
\end{abstract}

Copyright $(2017$ FEA-RP/USP. All rights reserved

\section{INTRODUCTION}

There is a growing call made in the literature to increase the practical relevance of accounting research (i.e. Jönsson, 1996; Malmi \& Granlund, 2009; Tucker \& Parker, 2014; Van Helden \& Northcott, 2010) for both managers and policy makers (Coleman, 2007; Swieringa, 1998). The academic/practitioner gap represents an unsolved issue still debated in many facets (Baldvinsdottir, Mitchell \& Nørreklit, 2010; Nørreklit, Nørreklit \& Mitchell, 2016; Tucker \& Lowe, 2014), showing the risk of developing a loop where academic research outputs produced only for academic researchers. In the context of public sector, in particular, we are observing many cases of difficulties and/or failures in bringing about accounting innovations (Arnaboldi \& Palermo, 2010) and producing practical relevant accounting research (Tucker \& Lowe, 2014), calling for developing research capable of delivering the advancement of both theory and practice. Professional bodies, as well as governments, are pushing universities towards the production of impact-related activities liaising more with the industry and/or the public sector institutions. This is particularly true in the UK and in Italy where universities are required to account for the impact the research activities have generated with an impact on the amount of governmental financing.

Method-wise, field research is considered a way through which answering the questions of practitioners and researchers alike (Hopwood, 2002; Lukka \& Mouritsen, 2002), trying to bridge academia and practice. Malmi and Granlund (2009) suggest three ways in which to produce practically relevant accounting theories, such as altering some current practices when conducting traditional research, using normative theories as a starting point, and adopting an interventionist research (IVR henceforth) methodology. On a similar manner, Van Helden and Northcott (2010: p. 231) suggest applying interventionist research approaches, engaging scholarship in order to both create new practice and find practical relevant theory or model. IVR can activate a learning process through the continuous collaboration and interaction between the concrete experiences and theoretical observation and development (Dumay \& Baard, 2017; Jönsson, 1996).

Corresponding author: Phone: +39 0532-293111

E-mail addresses: enrico.bracci@unife.it (E. Bracci)

University of Ferrara. Via Savonarola, 9, 44121 Ferrara FE, Itália. 
The interest on IVR is demonstrated by the increasing number of accounting studies published in primary international journals (i.e. Chiucchi, 2013; Dumay, 2010; Labro \& Tuomela, 2003; Lukka \& Suomala, 2014; Sunding \& Odenrick, 2010; Suomala, Lyly-Yrjänäinen, \& Lukka, 2014; Vagnoni \& Oppi, 2015; Westin \& Roberts, 2010), in books, book chapters and reports (Dumay \& Baard, 2017; Jönsson, 1996).

The aim of this paper is to present an analysis of the characteristics of IVR, providing guidance on how it can provide a fruitful methodology to contribute to both practical and theoretical development in the context of public sector research.

The rest of the paper is structured in the following fashion: the next section will provide an overview of what is and what is not an interventionist research. The third section will describe the steps to be followed in an IVR. Then the paper will detail the learning process an IVR can activate, before discussing some notable examples of IVR in the context of public sector organizations. Some final reflections will close the paper reflecting around the potentiality and risk of IVR research in public sector accounting.

\section{INTERVENTIONIST RESEARCH: what is and what is not}

The idea of adopting IVR derived from the seminal paper by Lewin (1946), in which he posited the idea of experiment change in the field rather than in an abstract (e.g. laboratory) context. IVR can be defined as a research strategy "to enter into an ongoing system of relationships, to come between or among persons, groups or objects for the purpose of helping them" (Argyris, 1970: 15). Fieldwork becomes a "total social situation" (Hastrup, 2005: p. 143), during which the researcher experience, interpret and evaluate as a "seamless whole". Action research is considered a relevant research strategy in order to work from within and developing new knowledge while unfolding the dynamics of practices (Shotter, 2003). In the words of Westin \& Roberts (2010: p. 8) "intervention research provides an understanding of how and why social life could be theoretically constructed as a joint creation between meaning, legitimacy and power in change processes". Such methodology is diffused in fields such as nursing, sociology, medicine and psychology, where field research to solve problems is considered a mainstream approach (Baard, 2010)

A more comprehensive definition of IVR can be the following, IVR is "a research methodology based on case study research whereby researchers involve themselves in working directly with managers in organisations to solve real-world problems by deploying theory for designing and implementing solutions through interventions, and analysing the results from both theoretical and practice perspective" (Dumay \& Baard, 2017).

The IVR aims at melding and contributing to theory (the etic) and practice (the emic) together, and express an entity of use as well as the explanation of use (Westin \& Roberts, 2010). The challenge for IVR in management accounting is experiencing practice in real terms and to deliver theory from it. According to Hastrup (2005), this research approach supports the meeting of practitioners and researchers, giving sense to reality through a theory building (Jönsson, 2010). This involves different way to studying control systems, as socio-technical artefacts as well as practices, increasing the links between researchers and managers (Berry, Coad, Harris, Otley, \& Stringer, 2009).

IVR needs not to be confused with other similar approaches used in different fields, such as action research (Eden \& Huxham, 1996), action science (Argyris, Putnam, \& McLain Smith, 1985) or constructive research (Kasanen, Lukka, \& Siitonen, 1993). Indeed, sometimes IVR is used as an umbrella term that includes the all above variations. According to Baard (2010), IVR should instead be considered as a framework on its own, distinguished from action research and other approaches.

IVR can be considered as a form of longitudinal case studies (Jönsson \& Lukka, 2005), during which the researcher is deeply involved with the object of study with an active role aimed at contributing to solving practical problems (Jönsson \& Lukka, 2006). Whilst in traditional case study research the researcher observes how managers behave or perceive a certain phenomenon, in IVR the researcher is involved in finding a solution for a specific practical problem. IVR is problem-solving oriented as the researcher typically participates in an innovation project by providing expert knowledge (Jönsson, 2010; Sunding and Odenrick, 2010). In non-interventionist case research, the primary target of the researcher is to test or refine hypothesis coming from prior theory and paying attention to the generalisation of the findings (Eisenhardt, 1989). The analysis is typically ex-post, looking back on what, how and why some events occurred in the case study. In such cases, the main source of evidence is based on interviews and document collections, rather than direct observation of the events. For IVR, the ex-post facto analysis is not an issue since the research must run synchronically with the flow of events. As Jönsson \& Lukka (2005: p.7) argue: "an interventionist researcher conducts her empirical research in vivo." 
In what IVR does not differ from non-interventionist case study is the attempt to make sense of what is going on in a particular case, and to provide a reliable explanation. The main difference, thus, is in the role of the researcher, his/her position within the case, and the dual output of the research.

One of the main advantages, as well critical issues, in applying IVR is the possibility to contribute both to the theoretical domain (etic) and to the practical domain (emic). As depicted in the following Figure 1, the process of scientific discovery is not linear, nor simple. Starting with the researcher getting and negotiating the access to an organization for a longitudinal period of observation.

The researcher may or may not enter the case site, once authorized, with a specific research question and motivation. The access to a research site to conduct an IVR is not obvious since there are legitimation, ethical and practical issues involved and a research may never get the chance to be granted of (Dumay \& Baard, 2017).

The theoretical reflection needs to go in parallel with the practical reflection on the state of the art of the organization and how it would need to evolve in the future to solve the problems (Lukka \& Vinnari, 2017). In the emic side, the theoretical solution is implemented and change occurs, assessing whether the problem was solved and through which practical means. Finally, the researcher observing the practical means of intervention develops a so-called reverse engineering during which attempt to go back to theory and assessing the theoretical contribution of the observations made.

The value added of IVR, as well as its complexity, is related to the adoption of both the emic and the etic viewpoint, meaning the attempt to link the practical solution (emic) to a theoretical frame in order to develop a theoretical contribution (etic). The researchers need to adopt both perspectives, shifting between the different logics of the two domains. During the emic mode, the researcher acts as an insider of the organization, being considered "one of us", allowing to collect empirical material of the highest quality (Jönsson, 1996; Suomala et al., 2014). Such duality does not represent a limitation in terms of "neutrality" of the researchers since IVR is compatible with very different epistemological approaches from positivistic to critical studies (Lukka, Vinnari, 2017).

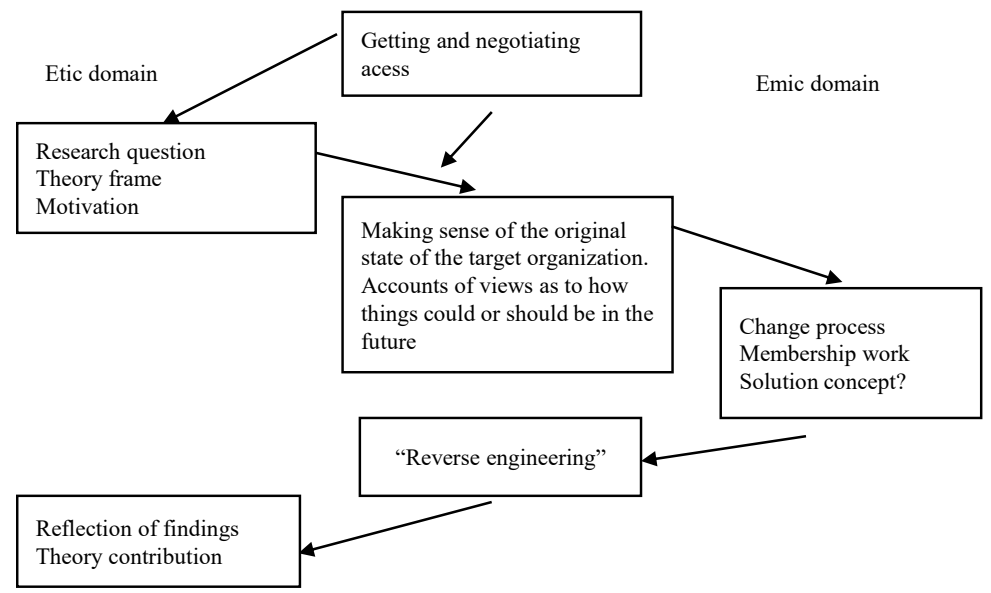

Figure 1. Interventionist research process: an example Source: Baard (2010).

IVR in its phases reveals many challenges for a researcher, particularly for young scholars (cf. Jönsson, 1996, 2010; Jönsson \& Lukka, 2006; Suomala \& Lyly-Yrjänäinen, 2012; Suomala et al., 2014). Firstly, to get an access to the organization(s) is not straightforward nor obvious and it may take time or never happen (Dumay, 2010). IVR, as a longitudinal case study, is time-consuming, which can be an issue for the researcher in many ways, since it may mean to wait three or more years before publication (Suomala \& Lyly-Yrjänäinen, 2012). Besides, shifting between the emic and etic modes can be difficult to untangle. In particular, there is the risk of going so "native" during the emic mode that a neutral attitude, necessary in the etic mode, is no more possible (Jönsson \& Lukka, 2006). It may also require skills and knowledge both from the research side and the practical side (Dumay, 2010).

In addition, the researcher may also be at risk of causing damage to the host organization, so he/she has to be cautious of the potential "elephant in the china store" effects (Jönsson \& Lukka, 2006), as well of preserving business secrets. 


\section{IVR AS A METHODOLOGICAL FRAMEWORK: a processual and learning perspective}

Many scholars have attempted to provide a conceptual framework for IVR. With specific reference to management accounting studies, Jonsson and Lukka (2006) proposed the following model (Figure 2). The model is characterised by five stages that the researchers need to experience in an IVR. As figure 2 shows, the researchers will develop both a conceptual and practical interaction with the practitioners, combining the academic logic with the practical logic of the fields.

The roles of the researcher and practitioner interact along several phases of the process. As Labro and Tuomela (2003) show in their paper, during an IVR the researcher should:

1. Find a practically relevant problem that also has research potential. Theoretical significance must be identified;

2. To examine the potential for long-term research co-operation with the target audience, including available resources;

3. Obtain a general and comprehensive understanding of the topic. Knowledge from previous literature required;

4. To innovate and construct a theoretically grounded solution idea and to implement the solution and test whether it works in practice;

5. To examine the scope of the solution's applicability (including issues of validity);

6. Show the theoretical connections and the research contribution of the solution.

The above steps are proposed also to assess the scientific validity and reliability of IVR. This is an important issue since IVR is often referred to as a form of case study or a kind of "field experimentation" (Jonsson \& Lukka, 2007), which is subject to criticism regarding their ability to achieve scientific research criteria of validity and reliability.

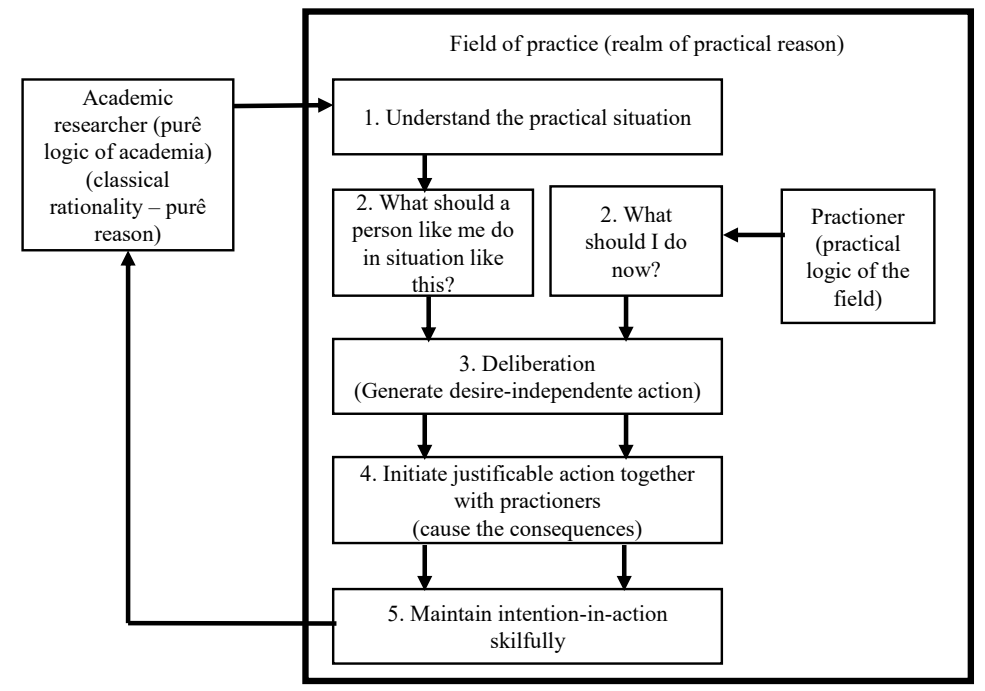

Figure 2. IVR model

Source: Jonsson \& Lukka (2007).

Labro \& Tuomela (2003) suggest that steps 3, 4 and 5 are related to ensuring internal validity, during these steps the authors identified the validity threats and implement the combatant strategies. Step 6, instead can be referred to assess external validity issues, that relates to the generalisation of the practical solution and the surrounding theorization, which means the transferability in other contexts. Kasanen et al. (1993) provides a three level validity test for IVR, where a weak external validity (or market test in the words of Kasanen et al. 1993 ) is achieved if the participant accepts to implement the proposed solution; a semi-strong external validity is passed if the adoption is extended to other organizations, while a strong external validity is achieved if organizations systematically employ the practical solution. 
Satisfying the external validity issue means the ability to produce practical relevant new knowledge in the process. The learning activated during an IVR is a key point in motivating and explaining the value added of such methodological approach (Chiucchi, 2013a; Jönsson, 2010).

Put in a schematic way, Avenier \& Noury (1999) depict clearly the IVR process from a knowledge creation perspective spawning from the interactions between the practitioners and researchers (Figure 3). Indeed, IVR presupposes action (Argyris et al., 1985) in an organizational setting engaging members and their competence with those of the researchers. Interventions force members and researchers to learn in a different way, since, they require to work in practice as well as provide theoretical insights (Lukka, 2007). As a consequence, particular attention needs to be paid by the researcher to context and the process of learning (Jönsson, 2010; Schatzki, 2002).

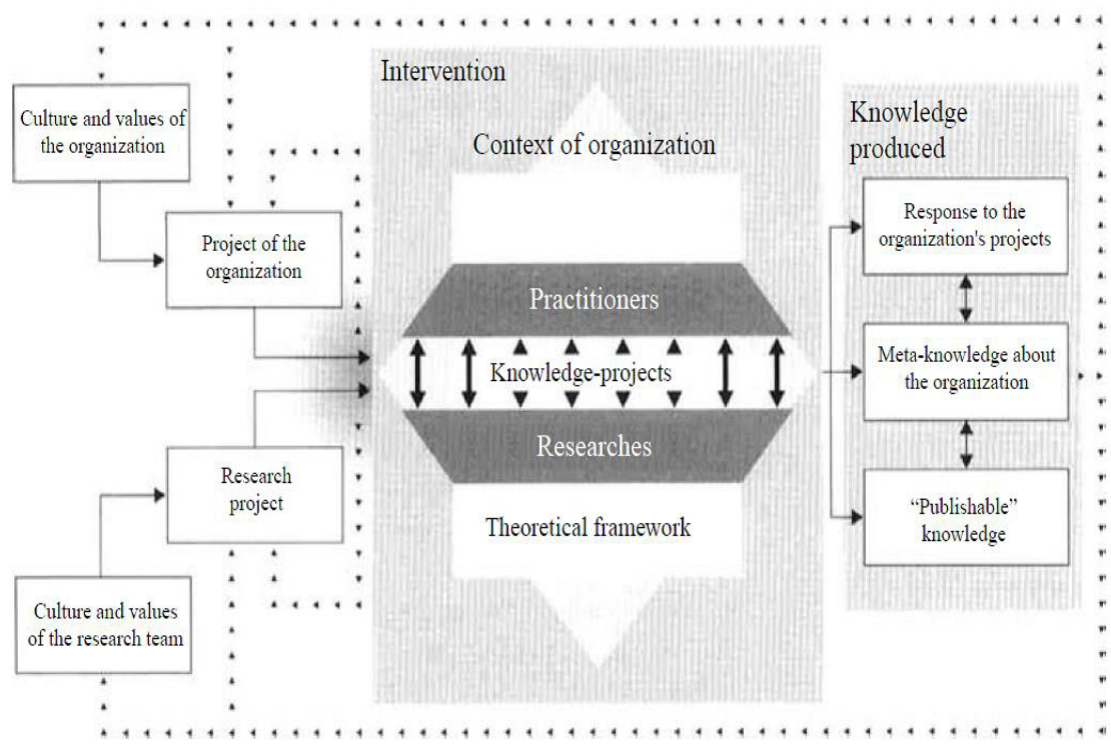

Figure 3. Intervention research process: a schematic representation Source: Avenier \& Nourry (1999).

Therefore, IVR involves a learning process during the continuous dialogue between the researcher and the organisational members. The learning process produces both practical and theoretical knowledge in interactive ways. In order to appreciate and understand how such learning is produced, the literature often refers to the Experiential Learning Theory (ELT) developed by Kolb $(1976 ; 1983)$. The ELT has been used in several IVR research in accounting (Chiucchi, 2013a; Jönsson, 1996). In particular, Jönsson (1996) argued that innovation and improvements are accomplished through a learning process within given structures. In this learning process, accounting plays a dual role, both as a constructed knowledge, but at the same time activate learning and other forms of knowledge (Jönsson, 1996). Indeed, learning occurs if a person is given a change, and if he/she are used to being held responsible for actions that he/she develops.

Kolb developed the ELT by drawing from the tradition of Piaget (cognitive development), Dewey (philosophical pragmatism) and Lewin (social psychology). Kolb defines learning as "the process whereby knowledge is created through the transformation of experience. Knowledge results from the combination of grasping and transforming experience" (Kolb, 1983, p. 41).

Experiential learning can be conceived as a four-stage cycle (see figure 3), namely: Concrete Experience (CE), Reflective Observation (RO), Abstract Conceptualisation and generalization (AC) and Active Experimentation (AE). $\mathrm{CE}$ is the starting point during which an actor can observe and reflect by experiencing without bias. An individual person starts learning by feeling through experience the tangible, felt qualities of the outside world. RO refers to a moment in which an actor starts to make sense of his/her own experience by watching and reflecting. $\mathrm{AC}$ involves the ability to conceptualise his/her observation through referring to concepts, theories or models. In this phase, thinking about, analysing and systematizing reality are the guide.

The selected concepts, theories or model then should be applied developing an active experimentation (AE), creating new experiences and reigniting the learning process. In an IVR the researcher should go through the four phases, making sure he/she has concrete experiences (emic), after which a reflective observation follows (etic), in order to develop new theories and eventually creating new practical experiences (Dumay \& Baard, 2017). 


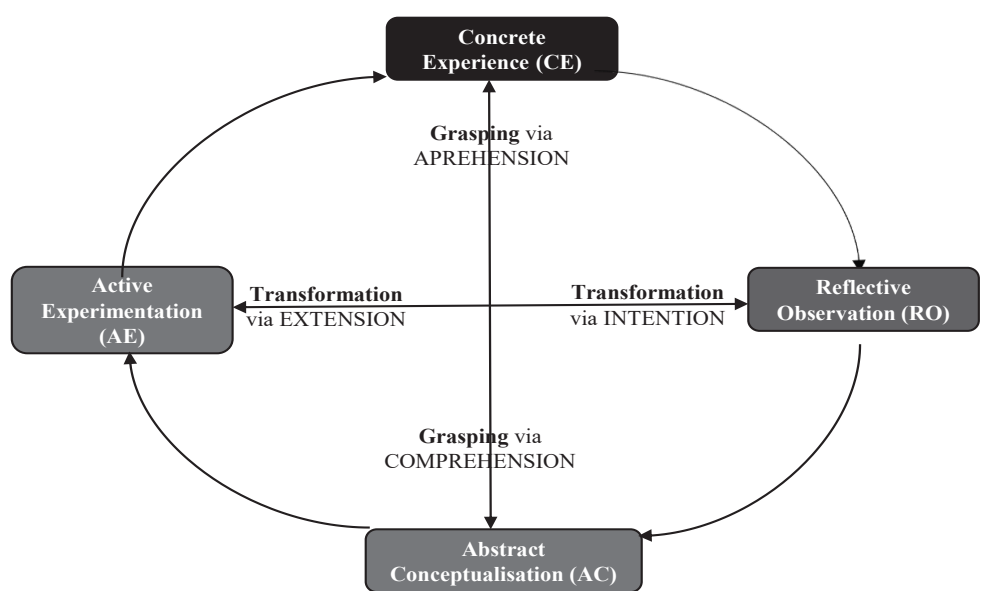

Figure 4. The Experiential Learning Theory (ELT) model Source: Adapted from Kolb (1976).

The ELT attributes to experience a central role in the learning process of individuals and groups. In particular, two are the main learning dimensions (Kolb, 1983):

- Prehension: relates to the connection between CE and AC. If learning relies on conceptual interpretation to understand the concrete experience, then we talk about comprehension, on the contrary, we talk about apprehension. Comprehension style refers to the conceptual interpretation and symbolic representation of experiences. Through comprehension, we attempt to create order of the seamless set of experiences made. In comprehending reality, we also can communicate our experience by using concepts and symbolic representations. Apprehension style, instead, is characterised by the reliance on tangible, immediate experience and the felt qualities of the outside world. It allows predicting and recreating the tangible experience made.

- Transformation: relates to the connection between RO and AE, and the learning pair of extensionintention. They equate to the two dimensions of semiotics, the syntactic (Intention) and semantics (Extension) (Kolb, 1983). With intention, Kolb refers to the reliance on conceptual interpretation and symbolic representation of the observed reality through an internal reflection. We may talk of extension when there is an external manipulation of the world or the extensional denotation of signs and symbols through which we refer to the real objects.

The creation of knowledge is the result of the combination of grasping experience (prehension) and transforming it with no predefined path (Kolb, 1983). The learning process is effective if all four phases are experienced and some form of prehension and transformation happen (Kolb, 1983).

ELT is considered a useful framework in order to understand the learning process of actors (Chiucchi, 2013a; Jönsson, 1996) and, on this vein, the path of design, implementation and adaptation of management accounting innovations. Kolb suggests that ELT can apply to both individuals and groups. In particular, at the beginning of a learning process, the group can represent the area of analysis. Then, every actor can experience different learning path and contribute differently within the group. As Dumay \& Baard (2017) argue, during the IVR the knowledge produced is the results of researchers and/or the practitioners going back and forth the four phases of the learning process.

\section{IVR IN PUBLIC SECTOR ACCOUNTING}

In the accounting field the adoption of IVR is still limited and most of the accounting examples of IVR fall in the domain of management accounting (Lyly-Yrjänäinen \& Suomala, 2012; Wouters \& Roijmans, 2011; Wouters \& Wilderom, 2008). Management accounting appears to be the most fruitful area in which IVR can bring together academic scholars and practitioners to solve complex organisational problems. In public sector, as a context, limited have been the contributions, with some notable exceptions to date (Arnaboldi \& Azzone, 2004; Dumay, 2010; Vagnoni \& Oppi, 2015), which I will now describe to give a flavour on what IVR means for accounting studies in the public sector. 
Arnaboldi and Azzone (2004) developed an IVR in the context of an Italian university, by looking at the construction and use of activity-based costing (ABC) system to benchmark departments cost performance. In their paper, the authors show both the technical aspects of implementing an activity-based system in the university and the analytical scheme used for decisions and the related behavioural issues. The practical problem was how to design and implement an ABC system in a university context. Theory-wise, Arnaboldi and Azzone (2004) drew on the work of Demski \& Feltham (1976), referring to the two main roles for managerial accounting: decision facilitating and decision-influencing, showing how the accounting systems can influence peoples' decisions and the alignment of their objectives to the organisational strategy.

Dumay (2010) carried out an IVR within the Sydney Conservatorium of Music (the Conservatorium), the latter being a part of the University of Sydney. The problem was the revision of the strategic planning of the Conservatorium. This project involved the Board of Advice to the Conservatorium, an external consultant (the researcher), the academic staff and the professional support staff of the Conservatorium. The result of this project was the creation of the strategic plan document. The researcher was engaged by the Conservatorium to drive the project and to be responsible for delivering the final document. One of the issue to be solved is to distinguish a plain consultancy intervention from a research one. Dumay (2010) contended that in an IVR, during the research design and development, what is essential is the combination of the Emic (inside) consulting/research problem and the Etic (outside) purposeful theoretical frame(s) utilised. In his study, he applied different theoretical constructs Narrative Theory (Joerges \& Czarniawska, 1998), IC Theory (Cuganesan, 2005; Skoog, 2003), Micro-sociological Theory (Westley, 1990), Sense-making and Narrative Theory (Weick, 2001; Weick \& Browning, 1986).

Vagnoni and Oppi (2015) looked at the design and implementation of an intellectual capital (IC) framework in a University-Hospital in Italy. In particular, the authors aimed at applying an IC framework to enhance the visualisation of strategic IC, enhancing the use of IC visualisation for strategic management and investigating the factors that are the foundation of the integration between hospital and university. They placed their theoretical contribution within the IC accounting studies deepening how the visualisation of the IC can foster the strategic process of healthcare organisations. At the same time, Vagnoni and Oppi (2015) contributed to the practical learning of public sector managers on how to design and develop an IC statement and the possible use, particularly to guarantee integration between the healthcare services and academic activities.

The three IVR cases help in describing the main characteristics, as well as the potentiality of this methodology. In all cases, the interventions lasted less than one year. In Dumay (2010), the intervention lasted only three months, demonstrating that if a researcher has a good access to the site, the research can be carried out in a reasonable period. As argued in the prevision sections, IVR allows for the adoption of different epistemological approaches. Arnaboldi and Azzone (2004) used a functionalistic approach by referring to Demski and Feltham (1976), while Dumay (2010) used a multi-theory approach, and Vagnoni and Oppi (2015) positioned their findings within the general IC theory. Overall, the three cases share the common aim at solving a practical problem (ABC implementation, IC reporting, and Strategic Plan), but at the same time contributing to the theoretical development.

\section{FINAL REFLECTIONS}

The above examples of IVR in the public sector can represent a reference point for young and emerging scholars to appreciate its values, principles and potentialities. Indeed, IVR continues to attract the interest of accounting scholars as a research methodology, despite the continuing debate on its scientific value and the critics of being no more than a consultancy intervention (Baard, 2010; Lukka \& Suomala, 2014). At the same time, it is important to have clear in mind that to conduct an IVR requires a methodological rigour to pass both the validity and reliability tests on which the paper will be assessed by potential referees.

At the end of this analysis, some final considerations may be put forward. IVR allows engaging with practitioners and policy-makers in their daily experience, having the possibility to observe and go deeper in the understanding of organisational dynamics. Therefore, the researchers can develop a dialectic between the emic and the etic to stimulate the generations of practical relevant managerial knowledge and technical solutions. This is particularly relevant in public sector organisations where the complexity of problems and the indeterminacy of solutions always require a case sensitive interventions. In so doing, the researcher can explore how public sector accounting practices and techniques can help in solving these problems, without compromising the quality of research (Jönsson \& Lukka, 2005). 
IVR as a methodology offers the possibility to adopt a different epistemological stance since it is not limited to normative or more functional approaches, but also allows for critical, interpretative and emancipatory approaches (Lukka \& Suomala, 2014). The discriminatory aspect in IVR with respect to non-interventionist research refers to the role of the researcher. In IVR the researcher is not a neutral observer of reality, but he is an active actor contributing to the discovery process, but allowing to bridge the epic (theoretical advancement) and the emic (practical advancement).

There are also some drawbacks in IVR, but in dealing with nowadays complexity of public sector and the social challenges governments have to cope with, researchers need to descend from their "ivory tower" to engage with practitioners and policymakers in order to stop being a neutral observer of the changes but an actor of change themselves.

\section{REFERENCES}

Argyris, C. (1970). Intervention theory and method: a behavioural science view. Reading, MA: Addison-Wesley.

Argyris, C., Putnam, R., \& McLain Smith, D. (1985). Action science - Concepts, Methods and Skills for Research and Intervention. San Francisco: Jossey-Bass.

Arnaboldi, M., \& Azzone, G. (2004). Benchmarking University Activities: An Italian Case Study. Financial Accountability and Management, 20(2), 205-220.

Arnaboldi, M., \& Palermo, T. (2010). Translating ambiguous reforms: Doing better next time? Management Accounting Research, 22, 6-15.

Avenier, M.-J., \& Nourry, L. (1999). Sciences of the Artificial and Knowledge Production: The Crucial Role of Intervention Research in Management Sciences. Design Issues, 15(2), 55-70. Retrieved from http://www. jstor.org/stable/pdf/1511842.pdf?refreqid=excelsior:24c5e6ae97acb3b59a62f3dd61c563a3

Baard, V. (2010). A critical review of interventionist research. Qualitative Research in Accounting \& Management, $7(1), 13-45$.

Baldvinsdottir, G., Mitchell, F., \& Nørreklit, H. (2010). Issues in the relationship between theory and practice in management accounting. Management Accounting Research, 21(2), 79-82.

Berry, A. J., Coad, A. F., Harris, E. P., Otley, D. T., \& Stringer, C. (2009). Emerging themes in management control: A review of recent literature. The British Accounting Review, 41(1), 2-20.

Chiucchi, M. S. (2013a). Intellectual capital accounting in action: enhancing learning through interventionist research. Journal of Intellectual Capital, 14(1), 48-68.

Chiucchi, M. S. (2013b). Measuring and reporting intellectual capital: Lessons learnt from some interventionist research projects. Journal of Intellectual Capital, 14(3), 395-413.

Coleman, H. (2007). New development: Connecting public service researchers and practitioners. Public Money and Management, 27(4), 281-284.

Cuganesan, S. (2005). Intellectual capital in action and value creation. Journal of Intellectual Capital, 6(3), 357373.

Demski, J. S., \& Feltham, G. A. (1976). Cost Determination: A Conceptual Approach. Ames, IA: Iowa State University Press.

Dumay, J., \& Baard, V. (2017). An introduction to interventionist research in accounting. In Z. Hoque, L. D. Parker, M. A. Covaleski, \& K. Haynes (Eds.), The Routledge Companion to Qualitative Research Methods (pp. 265-283). New York: Routledge.

Dumay, J. C. (2010). A critical reflective discourse of an interventionist research project. Qualitative Research in Accounting \& Management, 7(1), 46-70.

Eden, C., \& Huxham, C. (1996). Action Research for Management Research. British Journal of Management, 7(1), $75-86$.

Eisenhardt, K. M. (1989). Building Theories from Case Study Research. Academy of Management Review, 14(4), $532-550$. 
Hastrup, K. (2005). Social anthropology. Towards a pragmatic enlightenment? Social Anthropology, 13(2), 133149.

Hopwood, A. (2002). "If only there were simple solutions, but there aren"t': some reflections on Zimmerman's critique of empirical management accounting research. European Accounting Review, 11(4), 777-785.

Joerges, B., \& Czarniawska, B. (1998). The question of technology, or how organizations inscribe the world. Organization Studies, 19(3), 363-385.

Jönsson, S. (1996). Accounting for Improvement. Elsevier. Retrieved from http://books.google.com/ books?id=4SPDxfXhWMUC\&pgis $=1$

Jönsson, S. (2010). Interventionism - an approach for the future? Qualitative Research in Accounting \& Management, 7(1), 124-134.

Jönsson, S., \& Lukka, K. (2005). Doing interventionist research in management accounting. Gothenburg: Gothenburg Research Institute.

Jönsson, S., \& Lukka, K. (2006). There and back again. Doing interventionist research in management accounting. In C. S. Chapman \& A. G. Hopwood (Eds.), Handbook of Management Accounting Research (pp. 375-397). Elsevier.

Kasanen, E., Lukka, K., \& Siitonen, A. (1993). The Constructive Approach in Management Accounting Research. Journal of Management Accounting Research, 5(Fall), 243-264.

Kolb, D. A. (1983). Experiential Learning. Prentice Hall.

Labro, E., \& Tuomela, T.-S. (2003). On bringing more action into management accounting research: process considerations based on two constructive case studies. European Accounting Review, 12(3), 409-442.

Lewin, K. (1946). Action Research and Minority Problems. Journal of Social Issues, 2(4), 34-46.

Lukka, K. (2007). Management accounting change and stability: Loosely coupled rules and routines in action. Management Accounting Research, 18(1), 76-101.

Lukka, K., \& Mouritsen, J. (2002). Homogeneity or heterogeneity of research in management accounting? European Accounting Review, 11(4), 805-811.

Lukka, K., \& Suomala, P. (2014). Relevant interventionist research: balancing three intellectual virtues. Accounting and Business Research, 1-17.

Lukka, K., \& Vinnari, E. (2017). Combining actor-network theory with interventionist research: present state and future potential. Accounting, Auditing \& Accountability Journal, 30(3), 720-753.

Lyly-Yrjänäinen, J., \& Suomala, P. (2012). Management accountin research in practice. New York, NY: Routledge.

Malmi, T., \& Granlund, M. (2009). In Search of Management Accounting Theory. European Accounting Review, $18(3), 597-620$.

Nørreklit, H., Nørreklit, L., \& Mitchell, F. (2016). Understanding practice generalisation - opening the research/ practice gap. Qualitative Research in Accounting \& Management, 13(3), 278-302.

P. Tucker, B., \& D. Lowe, A. (2014). Practitioners are from Mars; academics are from Venus? Accounting, Auditing \& Accountability Journal, 27(3), 394-425.

Schatzki, T. R. (2002). The site of the social: a philosophical account of the constitution of social life and change. University Park, PA: Pennsylvania State University Press.

Shotter, J. (2003). Wittgenstein's philosophy and action research. Concepts and Transformation, 8(3), $295-301$.

Skoog, M. (2003). Visualizing value creation through the management control of intangibles. Journal of Integrated Care, 4(4), 487-504.

Sunding, L., \& Odenrick, P. (2010). A method for action research interventions to improve joint problem solving in operational teams in the Swedish construction industry. Qualitative Research in Accounting \& Management, $7(1), 97-123$.

Suomala, P., Lyly-Yrjänäinen, J., \& Lukka, K. (2014). Battlefield around interventions: A reflective analysis of conducting interventionist research in management accounting. Management Accounting Research, 1-11. 
Swieringa, R. J. (1998). Accounting research and policy making. Accounting and Finance, 38(1), $29-49$.

Tucker, B., \& Parker, L. (2014). In our ivory towers? The research-practice gap in management accounting. Accounting and Business Research, 44(2), 104-143.

Vagnoni, E., \& Oppi, C. (2015). Investigating factors of intellectual capital to enhance achievement of strategic goals in a university hospital setting. Journal of Intellectual Capital, 16(2), 331-363.

Van Helden, J. G., \& Northcott, D. (2010). Examining the practical relevance of public sector management accounting research. Financial Accountability \& Management, 26(2), 213-240.

Weick, K. E. (2001). Gapping the Relevance Bridge: Fashions Meet Fundamentals in Management Research. British Journal of Management, 12(s1), S71-S75.

Weick, K. E., \& Browning, L. D. (1986). Argument and Narration in Organizational Communication. Journal of Management, 12(2), 243-259.

Westin, O., \& Roberts, H. (2010). Interventionist research - the puberty years: an introduction to the special issue. Qualitative Research in Accounting \& Management, 7(1), 5-12.

Westley, F. R. (1990). Middle managers and strategy: Microdynamics of inclusion. Strategic Management Journal, 11(5), 337-351.

Wouters, M., \& Roijmans, D. (2011). Using Prototypes to Induce Experimentation and Knowledge Integration in the Development of Enabling Accounting Information. Contemporary Accounting Research, 28(2), 708-736.

Wouters, M., \& Wilderom, C. (2008). Developing performance-measurement systems as enabling formalization: A longitudinal field study of a logistics department. Accounting, Organizations and Society, 33(4-5), 488-516. 